\title{
Super Large-Scale Filtered Tailing Disposal on Coal-Mining Subsidence Land
}

\author{
De-ming Zhang ${ }^{1}$, Shuai Li ${ }^{1 *}$, Xin-min Wang ${ }^{1}$, Yan He ${ }^{1,2}$ \\ ${ }^{1}$ School of Resources and Safety Engineering, Central South University, \\ Changsha 410083, P.R. China \\ ${ }^{2}$ Jiangxi Science and Technology Research Center for Work Safety, \\ Nanchang 330030, P.R. China
}

Received: 31 December 2016

Accepted: 8 February 2017

\begin{abstract}
This paper evaluates the feasibility and stability of the construction of a super-large-scale filtered tailings storage facility on coal-mining subsidence land. Properties of the coal gangue were analyzed by laboratory tests and change laws of the land subsidence were observed in the field. Comparisons of slope stability between the super large-scale filtered tailings storage facility and conventional tailings impoundment in normal, flooded, sustained rainfall, and strong earthquake conditions were conducted using Slide software. The results show that the filtered tailings storage facility has less chance of failure, lower seepage probability, and smaller impact scope than conventional tailings impoundment. With little free water in filtered tailings, the average slope safety factors of filtered tailings storage are as high as 1.78 in normal, 1.73 in flood, 1.18 in sustained rainfall, and 1.11 in a magnitude-8.0 earthquake. As an environmentally friendly, costeffective chain-cutting disaster mitigation measure, filtered tailings disposal shows great advantages in reducing tailing emissions, dam construction scale, and operational costs, improving water conservation, dam stability, and service life.
\end{abstract}

Keywords: super large-scale, filtered tailings storage facility, subsidence land, coal gangue, filtered tailings disposal, disaster chain, disaster mitigation

\section{Introduction}

The Sijiaying Iron Mine (Hebei Iron and Steel Group, China) is Asia's biggest iron mine, and produces more than 70 million tons of tailing slurry annually, with a mass concentration of $20 \%$ [1]. As villages and farmland surround the mine, building a conventional tailings impoundment (CTI) near the iron mine will require

*e-mail: shuaige@csu.edu.cn an area of $4.2 \mathrm{~km}^{2}$, the demolition of three villages, the relocation of 1,000 people, and a total investment of more than 500 million CNY. Furthermore, wastewater, gas, and residue will cause serious pollution issues, making it a significant danger source if the dam were to seep or break [2]. Under the context of farmland protection in China and the downturn in the iron ore market [3-4], such a large land expropriation and investment is impossible.

In the past 20 years, paste tailings have been proved to be an environmentally friendly, cost-effective backfill and tailings disposal method [5]. Fourie [6] analyzed the advantages of paste and thickened tailings technology 


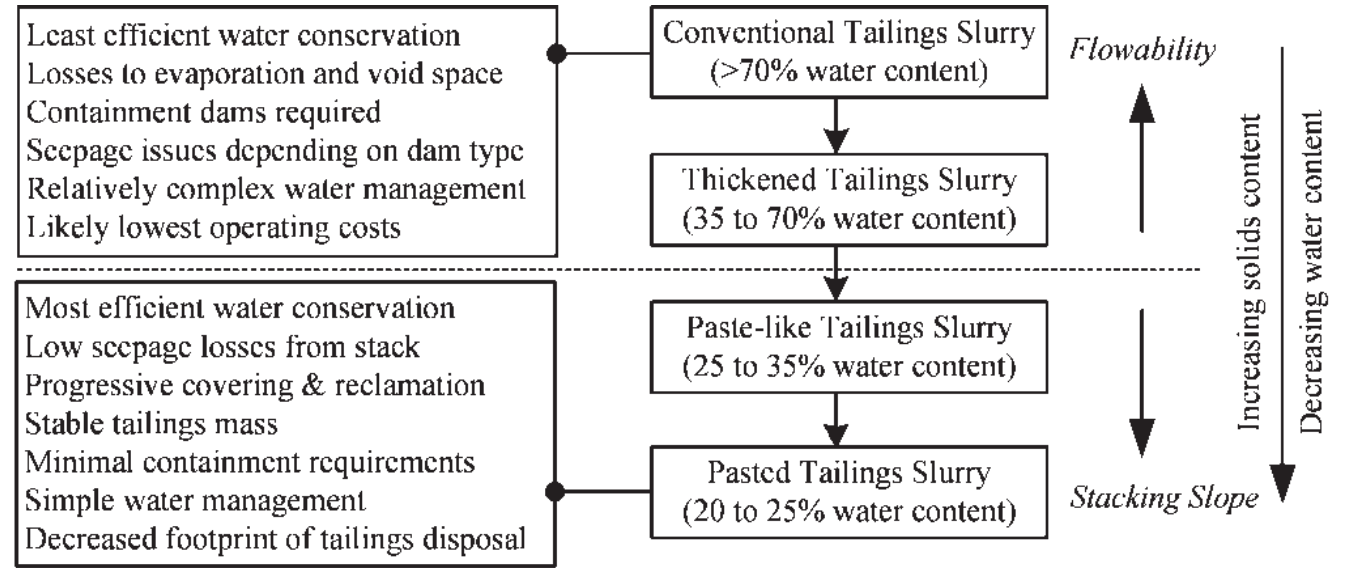

Fig. 1. Comparison of tailing slurries with different water content.

in stopes backfilling. An application of the paste tailings disposal on the surface in the Bulyanhulu mine has been reported by Theriault [7]. With little or no free water bleeding in nature (Fig. 1), paste tailings can be disposed of on the surface with low failure risks compared with CTI [8]. With a mass concentration of $68 \%$, the paste tailings slurry of Sijiying is still susceptible to liquefaction and the paste tailings dam is still a big dangerous source, especially in rain regions [9].

With the development of dewatering technologies and equipment, unsaturated filtered tailings disposal (FTD) has presented plenty of benefits for storing tailings over CTI or paste tailings [10]. In the FTD, tailings are stacked compactly, which potentially eliminates the tailing liquefaction dangers and reduces the potential seepage rates [11]. Lupo [12] proved that FTD can be a cost-effective tailings management method by analyzing several application examples. Newman [13] analyzed the superiority and proposed a detailed FTD design for the Rosemont copper mine.

Billions of tons of coal gangue output and millions of hectares of subsidence in coalfields are two prominent social and environmental problems related to underground coal mining in China [14]. According to statistics, the coal gangue output in 2015 was 720 million tons, and there are more than 2,600 gangue mountains in China [15]. However, the current recycling rate is only $60 \%$, and untreated coal gangue may pollute the landscape, water, soil, and atmosphere through dust generation. Besides, coal mining may cause large-scale and longtime land subsidence dangers, which has been a considerable threat to the large population and infrastructure of China. Considering that the land subsidence caused by underground coal extraction is a long and slow process, building a new tailings dam on coal-mining subsidence land may be feasible on the premise that the land subsidence is detected and treated in real-time. Meanwhile, coal gangue is rich in $\mathrm{Al}_{2} \mathrm{O}_{3}$ and $\mathrm{SiO}_{2}$ [16], making it a rich resource as well as a low-cost damming material.

A disaster chain, which is a brief summary of the different features of disasters, has been a live topic in disaster evaluation [17]. In this study, an innovative application of construction of a super large-scale filtered tailings storage facility (SFTSF) on coal mining subsidence land was conducted to get the 30 million tons/year tailings slurry of Sijiaying to be disposed of safely and effectively. A disaster chain model of the CTI was proposed according to the specific disaster-inducing factors of Sijiaying, and chain-cutting disaster mitigation measures were proposed.

\section{Feasibility Analysis}

\section{Feasibility of Construction of a Dam on Coal-Mining Subsidence Land}

Fangezhuang Coal Mine, one of the oldest and largest coal mines in Tangshan, China, is located $30 \mathrm{~km}$ west of the Sijiaying Iron Mine, and $14 \mathrm{~km}$ south of the Guye Area. After 30 years of coal mining, the subsidence area is more than $3.74 \mathrm{~km}^{2}$ and the average subsidence depth is about $5 \mathrm{~m}$. The existing stope is located between approximately 230 and $330 \mathrm{~m}$ depths. Bedrock above the stope is between 20 and $40 \mathrm{~m}$ thick, and there is a layer of Quaternary alluvium overlying the bedrock with an average thickness of $125 \mathrm{~m}$. The coal strata below the alluvium are Carboniferous and Permian systems. The floor of the coal bed consists of Ordovician limestone, and the roof is sandstone.

The influence of land subsidence on dam stability is the key factor in the feasibility analysis [18]. When a tailings dam is built above the stope the loading $q(X)$ will be greatly improved and settlement will be accelerated. According to the theory of key stratum in ground control [19], there are long, thick whole bed rock and Quaternary alluvial strata above the stope, which are seen as key strata for settlement calculation (Fig. 2).

Results show that settlement will increase at first, then decrease and reach stability following the tailings discharging process. The greatest settlement occurs in the center of the stope and will reach up to $1,630 \mathrm{~mm}$ until the dam is closed. As coal mining is still occurring 


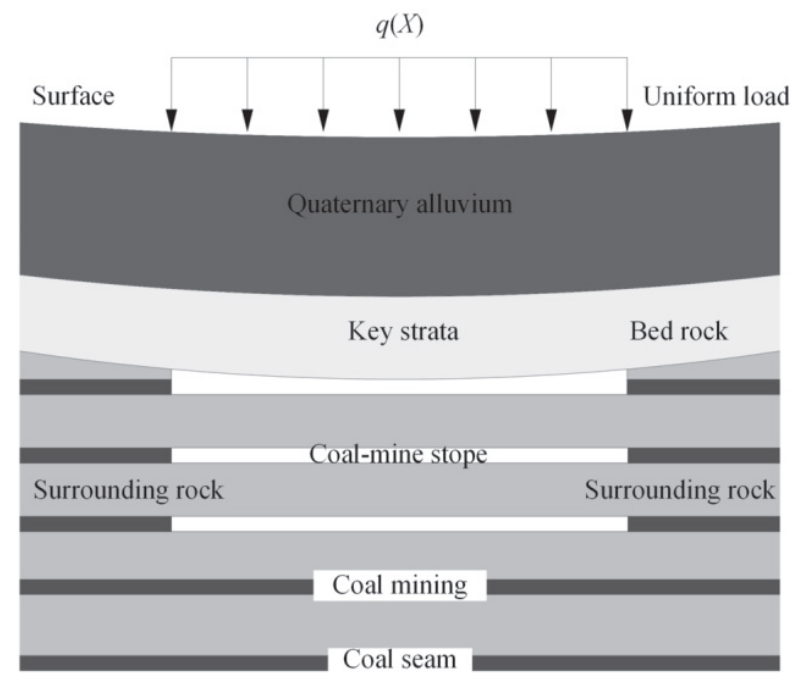

Fig. 2. Key strata model of the new SFTSF.

under the subsidence land, the stope will be destroyed and settlement will be accelerated by the drilling blast work. According to the mining plan for Fangezhuang, about two years of land settlement detection caused by coal mining is performed. The detection date is calculated using the probability integral method, and the results show that the greatest settlement is $2,600 \mathrm{~mm}$, the maximum gradient is $9.0 \mathrm{~mm} / \mathrm{m}$, and the maximum tensile deformation in the horizontal is $4.50 \mathrm{~mm} / \mathrm{m}$ until the dam is closed.

The maximum settlement caused by construction of a dam and underground coal mining lies in the center of the stope and will reach 4,230 $\mathrm{mm}$ over the whole service life. The service life of the SFTSF is 20 years, and the greatest land subsidence in a year is just $200 \mathrm{~mm}$. Compared with the long, slow settlement of subsidence land, the FTD rise rate is about 2,000 mm/a, which is 10 times the land settlement rate. Besides, the SFTSF will become increasingly stable with the compaction of coal gangue and filtered tailings during the stacks. In summary, avoiding building the dam in the center of the stope and strengthening the land subsidence detection can negate the negative influence on land subsidence.

\section{Feasibility of Coal Gangue for Damming}

There are more than 10 million tons of gangue in the Guye Area, Tangshan, occupying more than $100,000 \mathrm{~m}^{2}$ of land with an average height of $50 \mathrm{~m}$, making it a significant pollution and hazard source. Building the SFTSF will use about eight million tons of gangue and recover $90,000 \mathrm{~m}^{2}$ of land. As there are no suitable damming materials nearby, using coal gangue for damming purposes instead of buying sandy oil will save more than 200 billion CNY. Compared with using mining rock for damming, coal gangue will save more than 50 billion CNY in transportation costs.

The coal gangue is made up of sandstone and shale; the content of quartz and feldspar is more than $60 \%$ and the content of clay minerals is about $25 \%$ (Table 1 ). As is typical in alkaline waste residue, the oxide content of $\mathrm{Si}$, $\mathrm{Al}$, and $\mathrm{Fe}$ is more than $85 \%$. The content of $\mathrm{S}$ is less than $1.5 \%$, meaning that the coal gangue will not spontaneously combust under normal circumstances. The $\mathrm{pH}$ of gangue lixivium is 8.2 , and the total mineralization is 1,500 $\mathrm{mg} / \mathrm{L}$ less than the effluent standard. With a non-uniform coefficient of 6 and gradation factor of 2.5, the effective grain diameter of coal gangue is $0.32 \mathrm{~mm}$, the content of big coal gangue is less than $10 \%$, and only $3 \%$ of the content is smaller than $75 \mu \mathrm{m}$. The density is $2.6 \mathrm{~g} / \mathrm{cm}^{3}$ and the compressive strength calculated by unconfined compressive strength test is $67.5 \mathrm{MPa}$. The coal gangue shows good performance in softening resistance, slakedurability, and water stability, which can meet the working demands in water-related situations. The permissible deformation value of coal gangue as a damming material is $9.0 \mathrm{~mm} / \mathrm{m}$, which is twice the maximum horizontal tensile deformation calculated by direct tension tests.

A series of laboratory tests, such as petrographic composition, chemical component, leaching experiments, and physico-mechanical properties, show than coal gangue is similar to gravelly soil, has good performance in softening resistance, slake-durability, and water stability, and is an economic and environmentally friendly damming material.

\section{Feasibility of FTD}

The Sijiaying Iron Mine in Hebei, China, commissioned in 2007, is the largest underground iron mine in Asia to adopt an FTD solution. Backfilling stopes will use nearly half a portion and the remaining 30 million tons/year of argillized ultrafine tailings slurry will be 'stacked' on the surface. Fig. 3 presents a flow chart of the proposed preparation and transportation of filtered tailings in Sijiaying. Deep-cone thickener is used to obtain high concentration underflow by adding proper flocculants and coagulants to accelerate the settling velocity of fine tailings. With a solid concentration of $65 \%$, the underflow is transported to the filter-press plant by piston pumps in

Table 1. Physicochemical and mechanical properties of coal gangue.

\begin{tabular}{|c|c|c|c|c|c|c|c|c|}
\hline \multirow{2}{*}{ Properties } & \multicolumn{2}{|c|}{ Petrographic composition } & \multicolumn{2}{c|}{ Chemical component } & \multicolumn{3}{c|}{ Physico-mechanical properties } \\
\cline { 2 - 9 } & Quartz feldspar & Clay mineral & $\mathrm{SiO}_{2}$ & $\mathrm{Al}_{2} \mathrm{O}_{3}$ & $\mathrm{Fe}_{2} \mathrm{O}_{3}$ & $\begin{array}{c}\text { Softening } \\
\text { coefficient }\end{array}$ & $\begin{array}{c}\text { Saturation } \\
\text { coefficient }\end{array}$ & $\begin{array}{c}\text { Slake-durability } \\
\text { coefficient }\end{array}$ \\
\hline Range & $31 \sim 80 \%$ & $15 \sim 35 \%$ & $59 \sim 70 \%$ & $16 \sim 21 \%$ & $1 \sim 5 \%$ & $0.55 \sim 0.91$ & $0.31 \sim 0.91$ & $83 \sim 96$ \\
\hline Average & $60 \%$ & $25 \%$ & $65 \%$ & $18 \%$ & $3 \%$ & 0.76 & 0.59 & 0.89 \\
\hline
\end{tabular}






Fig. 3. Flow chart of a proposed FTD in Sijiaying.

a long-distance pipeline and then filtered, dumped, and stacked. Chamber filter press, which is well suited to the super-fine tailings in Sijiaying, shows great benefits in highly efficient energy-savings and easy maintenance. The benefits of Sijiaying in their decision to adopt an FTD solution include reduced land expropriation cost, saved water, and a decreased footprint of the tailings disposal site.

\section{Stability Analysis}

Slide is a slope stability software with built-in finite element groundwater seepage analysis for steady state or transient conditions [20]. A comparison of the slope stability factors (SSF) of the SFTST and CTI in normal, flood, sustained rainfall, and earthquake conditions was conducted by Slide.

\section{Introduction}

The newly designed dam on subsidence land is thirdclass and has a height of $42 \mathrm{~m}$. By covering $5.29 \mathrm{~km}^{2}$ of coal-mining subsidence land, the storage capacity of
SFTST is 168.45 million $\mathrm{m}^{3}$. With an average tailings particle size of $20 \mu \mathrm{m}$, the argillized ultrafine tailings slurry of Sijiaying is not suitable damming material. Therefore, coal gangue is used for damming the starter dam and sub dams. The height of the starter dam is $12 \mathrm{~m}$, and the dam structure is stiffened by high-strength geotextiles. With a $5 \mathrm{~m}$ wide dam crest, the upstream slope ratio of the dam is $1: 1.75$, the downstream slope ratio is $1: 2$, and the axis length is $3.8 \mathrm{~km}$. With an outside slope ratio of $1: 3$ and an inside slope ratio of $1: 1.5$, the height of the sub dam is $5 \mathrm{~m}$ and the dam crest is $2 \mathrm{~m}$ wide. There are six sub dams, and the dam crest is $+65 \mathrm{~m}$.

The geological section of CTI is shown in Fig. 4. The faster the slurry velocity, the further the tailings will be carried. Relatively coarse particles, such as fine sand tailings and silty sand tailings, will settle first and appear on the dry beach. Relatively fine particles such as silty soil tailings and clay-sized tailings will be transported further to the transition area and wateraccumulated area [21-22]. Unlike CTI, the filtered tailings composition is relatively singular and uniform after being filtered in the filter-press plant. Soil indicators of the main materials in the geological section are shown in Table 2 .

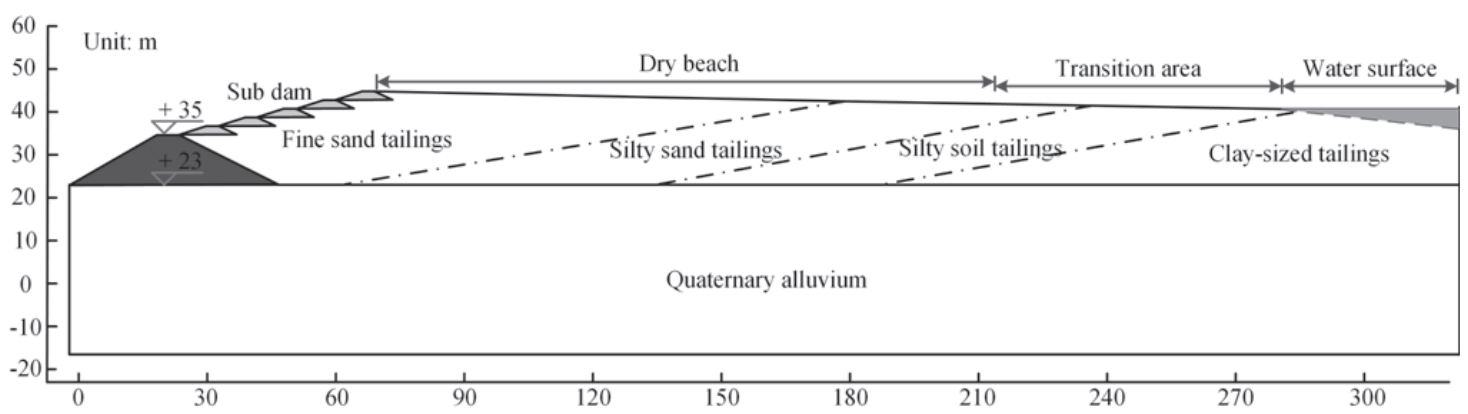

Fig. 4. Geological section of the CTI. 
Table 2. Soil indicators of main materials in the geological section.

\begin{tabular}{|c|c|c|c|c|c|c|c|c|}
\hline \multirow{2}{*}{ Names } & \multicolumn{2}{|c|}{ Volume-weight $/ \mathrm{kN} \cdot \mathrm{m}^{-3}$} & \multicolumn{2}{|c|}{ Soil indicators in nature } & \multicolumn{2}{c|}{$\begin{array}{c}\text { Soil indicators in } \\
\text { earthquake }\end{array}$} & \multicolumn{2}{c|}{$\begin{array}{c}\text { Osmotic coefficient } \\
/ \mathrm{cm}^{-1}\end{array}$} \\
\cline { 2 - 10 } & $\begin{array}{c}\text { Nature } \\
\gamma\end{array}$ & $\begin{array}{c}\text { Saturation } \\
\gamma_{\text {sat }}\end{array}$ & $\begin{array}{c}\text { Initial stress } \\
/ \mathrm{kPa}\end{array}$ & $\begin{array}{c}\text { Friction } \\
\text { angle } /{ }^{\circ}\end{array}$ & $\begin{array}{c}\text { Initial stress } \\
/ \mathrm{kPa}\end{array}$ & $\begin{array}{c}\text { Friction } \\
\text { angle } /{ }^{\circ}\end{array}$ & $\begin{array}{c}\text { Horizontal } \\
K_{1}\end{array}$ & $\begin{array}{c}\text { Vertical } \\
K_{2}\end{array}$ \\
\hline Quaternary alluvium & 19.6 & 20.8 & 4.5 & 28 & 230 & 36 & $7.42 \mathrm{E}-04$ & $6.38 \mathrm{E}-04$ \\
\hline Starter dam & 23.5 & 24.2 & 110 & 38 & 20 & 26 & $1.00 \mathrm{E}-01$ & $8.38 \mathrm{E}-02$ \\
\hline Fine sand tailings & 19.8 & 20.4 & 0 & 27 & 0 & 17.1 & $8.56 \mathrm{E}-04$ & $7.16 \mathrm{E}-04$ \\
\hline Silty sand tailings & 19.3 & 20.6 & 3 & 26 & 0 & 16.7 & $5.33 \mathrm{E}-04$ & $4.25 \mathrm{E}-04$ \\
\hline Silty soil tailings & 19.6 & 20.9 & 5.5 & 25 & 0 & 15.6 & $3.95 \mathrm{E}-04$ & $1.98 \mathrm{E}-04$ \\
\hline Clay-sized tailings & 18.7 & 19.2 & 9 & 23 & 0 & 15.4 & $8.80 \mathrm{E}-05$ & $8.22 \mathrm{E}-05$ \\
\hline Filtered tailings & 20.2 & 20.5 & 12 & 20 & 0 & 24.9 & $5.49 \mathrm{E}-05$ & $5.17 \mathrm{E}-05$ \\
\hline
\end{tabular}

\section{Stability Analysis in Normal Conditions}

The saturation line was also called the lifeline of CTI because nearly $25 \%$ of dam failure accidents are caused by the high position of a saturation line [23]. Filtered tailings are less than $100 \%$ saturated and non-segregating in nature, and then there is no saturation line in the SFTSF. The saturation lines of CTI, which were calculated by Slide using a finite element analysis method, are shown in Fig. 5.

To reduce the calculation error, SSF were calculated by Slide using the Bishop, Janbu, and Fellenuius methods [24]. By using the Janbu method, the calculated SSF of SFTSF and CTI are both higher than the safety level of 1.30 (Fig. 6), and the slopes show good stability in normal conditions.

\section{Stability Analysis in Flood Conditions and Sustained Rainfall}

Flooding is a dangerous source for CTI because the saturation line will increase quickly with plenty of water influx. SSF of CTI in flood conditions (with a water freeboard of $0.7 \mathrm{~m}$ ) using the Janbu method is just 1.13 (Fig. 7), which is lower than the safety level of 1.20 and prone to failure. Due to the low osmosis of filtered tailings, infiltration of free water is very slow in flood conditions, resulting in a low saturation line in SFTSF. The calculated SSF of SFTSF in flood conditions is still 1.69 and almost the same of that in normal conditions.

On sustained rainfall days, especially in rain seasons, tailings discharge is always halted and a series of drainage works will be implemented immediately. Then there is far less water influx in sustained rainfall than in flood conditions. However, the slope surface will be more than $100 \%$ saturated with long-time rain soaking, resulting in a high saturation line along the outside slope surface. Under the function of a high saturation line, the calculated SSF of SFTSF and CTI in sustained rainfall conditions are 1.17 and 0.92 (Fig. 8), respectively. As a consequence, the slope of SFTST is in the limit equilibrium state but still safer than CTI.

The SFTSF shows good stability in normal conditions and in flooding situations, but the failure probability will increase during periods of sustained rainfall. However,

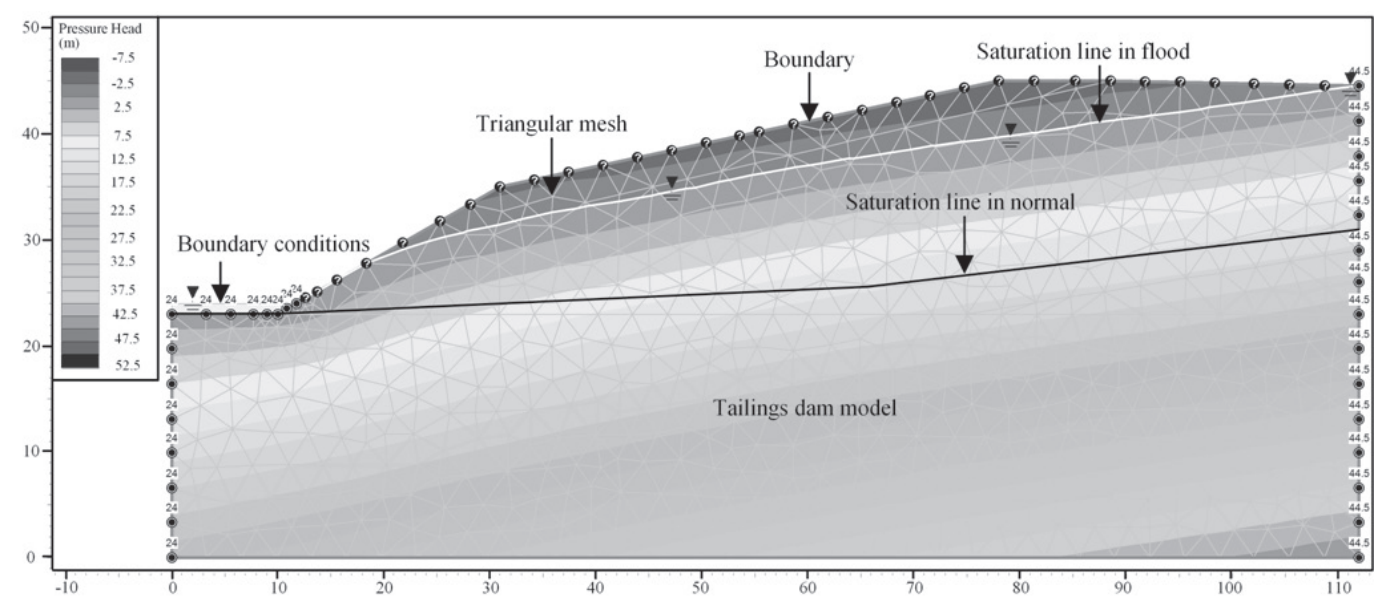

Fig. 5. The calculated saturation lines of the CTI of Sijaiying. 

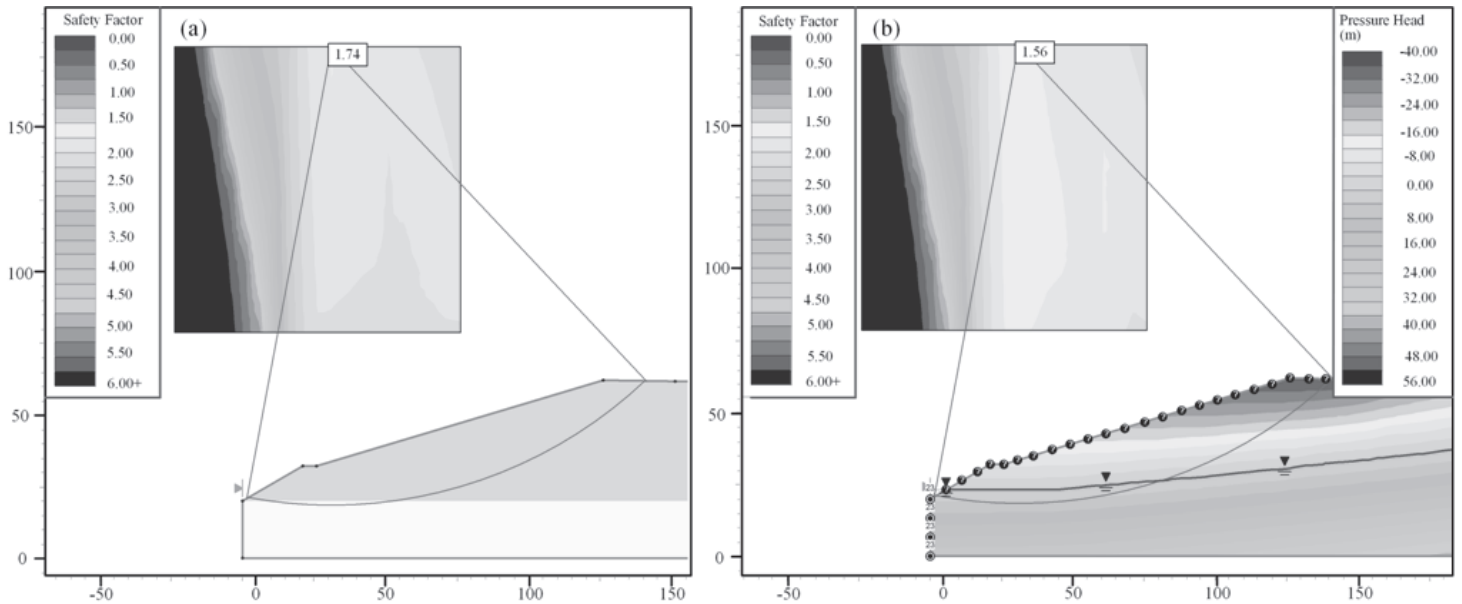

Fig. 6. SSF in normal conditions: a) SFTSF and b) CTI.


Fig. 7. SSF in flood conditions: a) SFTSF and b) CTI.
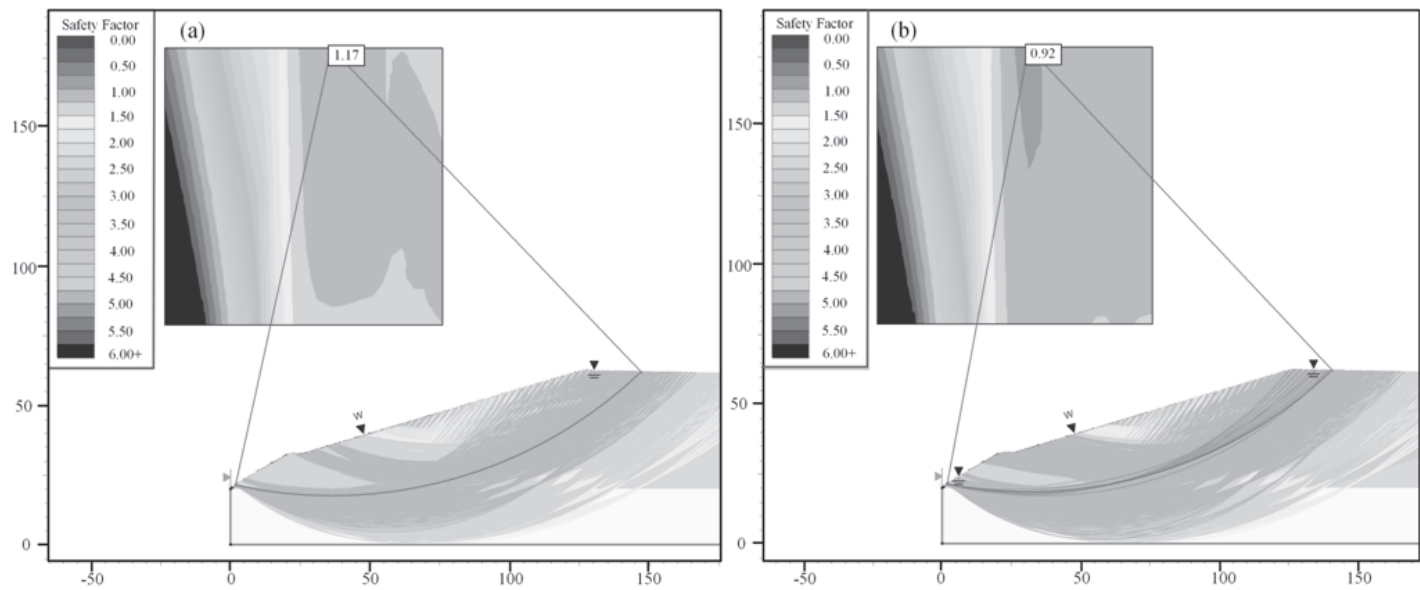

Fig. 8. SSF under sustained rainfall: a) SFTSF and b) CTI.

the climate of Tangshan is a sub-humid, warm temperate continental monsoon climate, with annual precipitation of only $524 \mathrm{~mm}$, and there are no large rivers. Therefore, it is unlikely that a big flood would occur within the service life of the new SFTSF [25]. There will occasionally be some sustained rainfall days in the summer, but the precipitation amount will be very small. Forecasting should be employed and defensive actions should be taken 

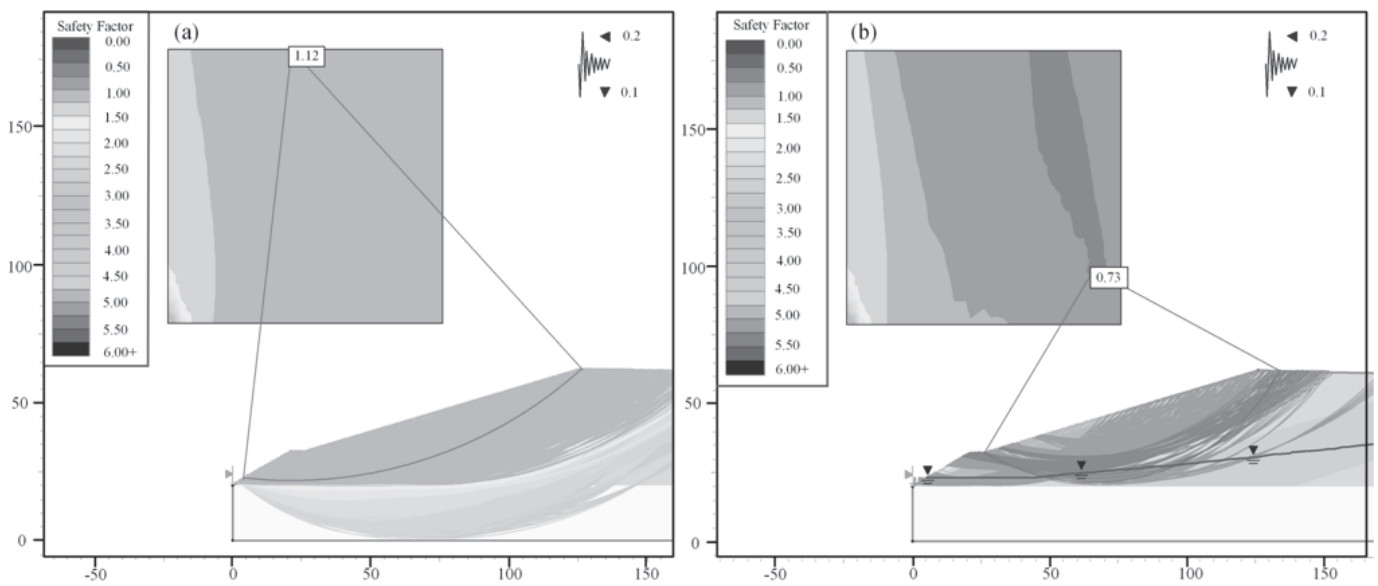

Fig. 9. SSF in a magnitude 8.0 earthquake: a) SFTSF and b) CTI.

in this situation, and then the negative influence of the rainfall can be ignored.

\section{Seismic Stability Analysis}

Earthquakes may have a destructive effect on dams. Tangshan suffers from frequent earthquakes, and a magnitude 7.8 earthquake struck in 1976. Therefore, seismic fortification of the SFTSF is set at a magnitude of 8.0, seismic acceleration in the horizontal to $0.2 \mathrm{~g}$, and seismic acceleration in the vertical to $0.1 \mathrm{~g}$. Tailings properties used for SSF calculation in an earthquake are shown in Table 2. The average SSF of the CTI is 0.74 (Fig. 9), which is far lower than the standard level of 1.10. Meanwhile, the average safety factor for the SFTSF in a magnitude 8.0 earthquake is about 1.11 (Table 3 ), which is in a limit equilibrium state.

Table 3 shows the calculated safety factors of the SFTSF and the CTI in the above-mentioned situations. Compared with CTI, the SFTSF has less chance of failure, lower seepage probability, and smaller impact scope since there is much less water containment.

\section{Disaster Analysis}

\section{Disaster Chain}

The formation mechanisms, evolution processes, and destructiveness of a disaster can be analyzed using disaster chains. The commonness or rarity of different disasters can be analyzed in depth and summarized, providing a firm foundation for future disaster prevention and control [26]. Under the actions of different disasterinducing factors like rainfall, flooding, earthquakes, and coal mining, disasters begin to appear in the preparation stage (Fig. 10). Several small disasters begin to appear continuously, for instance land subsidence, dam cracking, and piping. With continuous exposure to adverse factors, the development of disasters will be accelerated to the latency stage and a series of small disasters - like high saturation line, tailings liquefaction, and dam cracking - may appear in the latency stage and result in the final disaster's explosion stage. Destructive disasters like mudrock flow and landslides will outburst in the explosion stage and the disaster chain model of CTI is called the bursting and slippage chain [27]. Other chain-styled theoretic models, such as the creeping corrosion chain, the

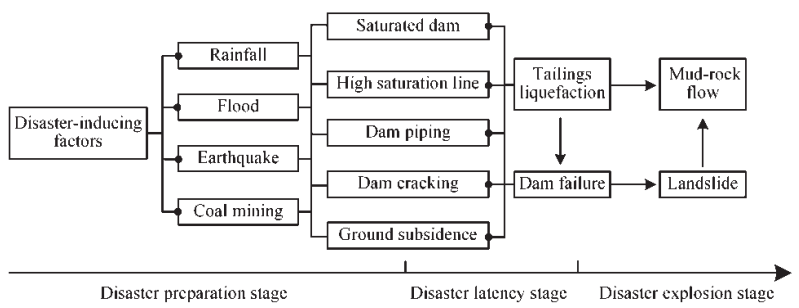

Fig. 10. Disaster chain model of the CTI in Sijiaying.

Table 3. SSF in different situations.

\begin{tabular}{|c|c|c|c|c|c|c|c|c|c|}
\hline \multirow{2}{*}{ Situtations } & \multicolumn{4}{|c|}{ CTI } & \multicolumn{4}{|c|}{ SFTSF } & \multirow{2}{*}{ Standard } \\
\hline & Bishop & Fellenuius & Janbu & Average & Bishop & Fellenuius & Janbu & Average & \\
\hline Normal & 1.64 & 1.57 & 1.56 & 1.59 & 1.83 & 1.76 & 1.74 & 1.78 & 1.30 \\
\hline Flood & 1.18 & 1.15 & 1.13 & 1.15 & 1.78 & 1.71 & 1.69 & 1.73 & 1.20 \\
\hline Sustained rainfall & 0.98 & 0.98 & 0.92 & 0.96 & 1.20 & 1.18 & 1.17 & 1.18 & 1.20 \\
\hline Earthquake & 0.78 & 0.72 & 0.73 & 0.74 & 1.13 & 1.08 & 1.12 & 1.11 & 1.10 \\
\hline
\end{tabular}






Fig. 11. Chain-cutting disaster mitigation measures.

periodicity repetition chain, the branch-haulm drainage area chain, the cut-and-fill sedimentation chain, and the radiation chain are also widely used in disaster analysis.

\section{Chain-Cutting Disaster Mitigation Technology}

Chain-cutting disaster mitigation technology is defined as a useful disaster control and loss reduction method that cuts off the disaster chain and prevents disaster development [28]. For the bursting and slippage chain of CTI in Sijiaying, corresponding chain-cutting disaster mitigation measures are shown in Fig. 11. Tailings reutilization, backfill, and dam reinforcement are all important and useful active prevention measures but cannot resolve the issue completely. FTD has been proven to be the most effective active prevention method. First, the most dangerous free water is separated from the stacked tailings, leading to the threatening saturation line far away from the SFTSF. Besides, SFTSF has less chance of seepage and lower potential destructiveness than that of CTI in flood, rainfall, and earthquake situations. Furthermore, the construction scale and costs will be reduced greatly while the storage and service life will be effectively improved. Detection, evacuation, and prevention are the core of passive defense measures [29]. According to potential disasters, a series of passive defense measures will be taken to reduce the disasters loss, which has been proven easy to implement while the results are not sufficiently effective.

\section{Conclusions}

To dispose of the 30 million tons/year Sijiaying tailings slurry safely and effectively, we conducted an innovative application of construction a SFTSF on coal mining subsidence land. Compared with the long, slow settlement of subsidence land, the FTD rise rate is about 10 times the land settlement rate, and the negative influence of land subsidence can be neglected. A series of laboratory tests shows than coal gangue has good performance in softening resistance, slake durability, and water stability. Therefore, construction of a new coal gangue-based SFTSF on coal mining subsidence land is safe, economical, and environmentally friendly.

The SFTSF shows good stability in normal conditions and flood situations. Safety factors under sustained rainfall and a magnitude 8.0 earthquake are 1.18 and 1.11 , respectively, which are both in the limit equilibrium state. Compared with the CTI, the SFTSF has less chance of failure, lower seepage probability, and smaller impact scope since there is much less water containment.

The failure type of the CTI in Sijiaying belongs to the bursting and slippage disaster chain. As an environmentally friendly, cost-effective chain-cutting disaster mitigation measure, filtered tailings disposal shows great advantages in reducing tailings emissions, dam construction scale, and operational costs, at the same time improving water conservation, dam stability, and service life.

The Slide simulations in this paper were conducted in only two dimensions. The calculation accuracy can be further promoted in the future by using 3-dimensional finite-element software.

\section{Acknowledgements}

The authors thank the financial support from the Fundamental Research Funds for the Central Universities of Central South University (No. 2015zzts078) and the Key Research and Development Plans of Jiangxi Province (No. 20161BBG70100).

\section{References}

1. LI S., WANG X.M., ZHANG Q.L. Dynamic experiments on flocculation and sedimentation of argillized ultrafine tailings using fly-ash-based magnetic coagulant. T. Nonferr. Metal. Soc. 7 (26), 1975, 2016.

2. SHEORAN A.S., SHEORAN V., CHOUDHARY R.P. Bioremediation of acid-rock drainage by sulphate-reducing prokaryotes: A review. Miner. Eng. 14 (23), 1073, 2010.

3. LICHTENBERG E., DING C. Assessing farmland protection policy in China. Land Use Pol. 25 (1), 59, 2008.

4. LAWRENCE K., NEHRING M. Market structure differences impacting Australian iron ore and metallurgical coal industries. Minerals. 5 (3), 473, 2015. 
5. YILMAZ E., KESIMAL A., ERCIKDI B., KAYA R. The use of paste for disposal of mill tailings. In $3^{\text {rd }}$ International Scientific Conference-SGEM2003. 109, 2003.

6. FOURIE A. Paste and thickened tailings: has the promise been fulfilled. P. Geologist. Assoc. 4126-4134, 2012.

7. THERIAULT J., FROSTIAK J., WELCH D. Surface disposal of paste tailings at the Bulyanhulu gold mine, Tanzania. Proceedings of Sudbury. 265, 2003.

8. NEWMAN P., WHITE R., CADDEN A. Paste, the Future of Tailings Disposal. Proceedings of the 2nd International Conference on Mining and the Environment. 594, 2001.

9. LI S., CHEN Q.S., WANG X.M. Superiority of filtered tailings storage facility to conventional tailings impoundment in southern rainy regions of China. Sustainability. 8 (11), 1130, 2016.

10. ŚLIWKA M., BARAN A., WIECZOREK J. Evaluation of toxic metal bioaccumulation in a reservoir of flotation tailings. Pol. J. Environ. Stud. 22 (3), 909, 2013.

11. DAVIES M.P., LUPO J., MARTIN T., MCROBERTS E., MUSSE M., RITCHIE D. In dewatered tailings practicetrends and observations. Proceedings of Tailings and Mine Waste. 10, 2010.

12. LUPO J, HALL J. Dry stack tailings-design considerations. Proceedings Fourteenth International Conference on Tailings and Mine Waste. 327, 2010.

13. NEWMAN L., ARNOLD K., WITTWER D. Dry stack tailings design for the Rosemont Copper project. International Conference on Tailings \& Mine Waste. 10, 315, 2010.

14. DONG S., SAMSONOV S., YIN H., YAO S., XU C. Spatiotemporal analysis of ground subsidence due to underground coal mining in Huainan coalfield. China. Environ. Earth Sci. 9 (73), 5523, 2015.

15. TIAN J.Y., YAO W. Research on the ecological restoration of coal mining subsidence area in Shanxi province. In Advanced Materials Research. 827, 384, 2014.

16. WANG, J., QIN, Q., HU, S., WU, K. A concrete material with waste coal gangue and fly ash used for farmland drainage in high groundwater level areas. J. Clean Prod. 112, 631, 2016.

17. XU M., WANG Z., QI L., LIU L., ZHANG K. Disaster chains initiated by the Wenchuan earthquake. Environ. Earth Sci. 65 (4), 975, 2012.
18. YIN G., LI G., WEI Z., WAN L., SHUI G., JING X. Stability analysis of a copper tailings dam via laboratory model tests: A Chinese case study. Miner. Eng. 2 (24), 122, 2011.

19. JU J., XU J. Structural characteristics of key strata and strata behavior of a fully mechanized longwall face with $7.0 \mathrm{~m}$ height chocks. Int. J. Rock. Mech. Min. 58, 46, 2013.

20. WALA M., MEHTA P., PATEL R. Study of stability of fly ash dam using slide software. Int. Edu. Res. J. 2 (1), 125, 2016.

21. VRHOVNIK P., DOLENEC T., SERAFIMOVSKI T., DOLENEC M., ROGAN ŠMUC N. The occurence of heavy metals and metalloids in surficial lake sediments before and after a tailings dam failure. Pol. J. Environ. Stud. 22 (5), $1525,2013$.

22. XU B., WANG Y. Stability analysis of the Lingshan gold mine tailings dam under conditions of a raised dam height. B. Eng. Geol. Environ. 1 (74), 151, 2015.

23. TONGLE X., YINGBO W., KANG C. Tailings saturation line prediction based on genetic algorithm and BP neural network. J. Intell. Fuzzy. Syst. 4 (30), 1947, 2016.

24. RABIE M. Comparison study between traditional and finite element methods for slopes under heavy rainfall. HBRC J. 10 (2), 160, 2014.

25. CAI W., ZHANG Y., YAO Y., CHEN Q. Probabilistic analysis of drought spatiotemporal characteristics in the Beijing-Tianjin-Hebei metropolitan area in China. Atmosphere-Basel. 4 (6), 431, 2015.

26. PENG J.B., SUN X.H., WANG W., SUN G.C. Characteristics of land subsidence, earth fissures and related disaster chain effects with respect to urban hazards in Xi'an, China. Environ. Earth. Sci. 75 (16), 1190, 2016.

27. GAO F., ZHOU K.P., CHEN X.Y., LUO X.W. Disaster chains induced by mining and chain-cutting disaster mitigation technology. Disaster. Adv. 5 (4), 971, 2012.

28. LAKSHMI M.R., KUMAR V.D. Anthropogenic hazard and disaster relief operations: A case study of GAIL pipeline blaze in east godavari of a.p. Procedia - Social and Behavioral Sciences. 189, 198, 2015.

29. WANG J., GU X., HUANG T. Using Bayesian networks in analyzing powerful earthquake disaster chains. Nat. Hazards. 2 (68), 509, 2013. 
